\section{CarakaTani \\ Journal of Sustainable Agriculture \\ ISSN 2613-9456 (Print) 2599-2570 (Online)}

\title{
An Analysis of Wheat Farming: Calculations and Perceptions
}

\author{
Damara Dinda Nirmalasari Zebua ${ }^{1 *}$, Sony Heru Priyanto ${ }^{2}$ and Lasmono Tri Sunaryanto ${ }^{2}$ \\ ${ }^{1}$ Magister Student of Agroecotechnology, Post-Graduate Program of Universitas Kristen Satya Wacana, \\ Salatiga, Indonesia; ${ }^{2}$ Department of Agroecotechnology, Post-Graduate Program of \\ Universitas Kristen Satya Wacana, Salatiga, Indonesia \\ *Corresponding author: damaradinda3@gmail.com
}

\begin{abstract}
National diversification of wheat-based food has been put into practice. Public consumption of flourbased food, such as noodles and bread, is in great demand. This study aims to determine the calculations, perceptions and attitudes of farmers towards wheat farming, considering that Indonesia is a non-wheat developing country. This qualitative descriptive research using in-depth interviews with 7 informants and observation methods was conducted in Klaten and Demak Regencies. In analyzing the data, this study used an interactive analysis model including data reduction, data presentation and conclusion drawing. The results show that: 1) based on farmers' calculations, wheat farming is financially not profitable to farmers because the products harvested are not worth the expense; 2) farmers' calculations affect farmers' perceptions which shifted to negative perceptions that wheat farming is not as promising as other farming businesses. Despite the negative perceptions, wheat farming has provided a valuable experience for farmers which is shown by their pride and pleasure and 3) the majority of farmers are not interested in wheat farming, which is shown by their attitude of not being able to accept wheat farming, while other farmers behave otherwise, indicated by their willingness to recommence wheat planting testing. Further research may examine: 1) how to change the culture of rice farming into culture of wheat farming; 2) how to change subsistence rice farming into enterprise and 3) how to change rice farming as social activities to rice farming as business activities.
\end{abstract}

Keywords: adoption, behaviours, cognitions, culture, expectations

Cite this as: Zebua, D. D. N., Priyanto, S. H., \& Sunaryanto, L. T. (2019). An Analysis of Wheat Farming: Calculations and Perceptions. Caraka Tani: Journal of Sustainable Agriculture, 34(2), 200-212. doi: http://dx.doi. org/10.20961/carakatani.v34i2.28862

\section{INTRODUCTION}

Food is the main basic need for humans that must be fulfilled at all times. For Indonesians, food is often identified with rice because it is the main staple food for them (Wahyuniarti and Prabowo, 2014). However, at this time, the majority of Indonesians have consumed bread and noodles made from wheat flour as the second staple food after rice (Sembiring et al., 2016). Similar idea is also stated by Rizka et al. (2018) in their research that rice is still the main source of carbohydrates and bread products are the second source of carbohydrates. It can be seen from the rapid increase of Indonesia's flour consumption from 5.5 to 17 grams capita $^{-1}$ day $^{-1}$ in the course of time from 1993 to 1996. From 1996 to 1999, it had declined to 15.4 grams capita ${ }^{-1}$ day $^{-1}$, but increased again from 1999 to 2002 to 21.7 grams capita $^{-1}$ day $^{-1}$ and continued to increase until 2005 to 27.3 grams capita ${ }^{-1}$ day $^{-1}$ (Hardinsyah and Amalia, 2007). This is affirmed by Pradeksa et al. (2014) in their research that the volume of wheat imports in Indonesia had increases year by year. Based on the trend calculation, the results have shown that there will be an additional import

\footnotetext{
${ }^{*}$ Received for publication March 23, 2019

Accepted after corrections July 31, 2019
} 
volume of approximately 11,793 tons every year. If Indonesia still relies on imports to fulfill the domestic needs, it will certainly absorb significant amount of foreign exchange that may influence the national food security. Therefore, it is the time for Indonesia to develop wheat to secure flourbased food sustainability (Baga and Puspita, 2013).

In Indonesia, wheat has considerable potential to be developed in the future, considering that the criterion for growing wheat crops at altitudes more than 800 meter above sea level (m.a.s.l.) is met and areas situated at the altitude are widely spread in Indonesia (Baga and Puspita, 2013). However, several obstacles have been identified during the development of wheat in Indonesia. For example most farmers are not familiar with wheat cultivation, also there is no market guarantee for the wheat products produced. In their research, Purnomo et al. (2010) have stated that farmers still highly lack of knowledge of wheat farming. There are a significant number of farmers who do not understand how to grow wheat, how the wheat crops look like, how the correct process of postharvest is, also where the wheat will be sold. It is also supported by Kurnia et al. (2016) in their research that the obstacles faced in the development of wheat are the lack of knowledge about wheat cultivation and the competition with other commodities that have been planted by farmers before. Therefore, wheat breeding program in Indonesia is directed at assembling superior tropical varieties that are able to adapt to the lowlands to moderate lands (Erythrina and Zaini, 2016).

Since 2001, Faculty of Agriculture and Business Universitas Kristen Satya Wacana has begun to introduce wheat crops to farmers through the introduction of wheat crops in several upland areas. In 2017, wheat crops were introduced to farmers in the lowlands on a large scale, to approximately $1 / 2$ hectare (ha) of land in Klaten and Demak Regencies. Both regencies are lowlands that have never been tested for wheat planting before. Besides, wheat varieties used in the two regencies are lowland wheat varieties. For farmers in both regencies, wheat is an innovation. According to Rogers (1983), innovation is an idea, practice or object that is considered as something new by individuals or other group units. The perception of farmers in assessing innovation is closely related to the adoption of the innovation. The rate of adoption of an innovation depends on the perception of the adopter about the characteristics of the innovation. The characteristics of these innovations include relative advantages, compatibility, complexity, ability to experiment and observability.

Schiffman and Kanuk (2008) in their book have revealed that in the theory of learning, someone who has tried to do something new will experience something about it. After experiencing one-time learning, the person will experience a process of calculation. The process will usually continue with the process of the appearance of perception. Someone will usually give a direct response from something that is received through the five senses, which is known as perception. Perception is the work of the brain in understanding or judging something that happens around it. After individuals interact with the perceived objects, the results of perception have two possibilities, namely positive perceptions that describe the knowledge and responses that continue on to the utilization efforts, and negative perceptions that describe knowledge and responses that are not in harmony with the perceived object. Perception will usually be demonstrated and showed in the attitudes or tendencies of farmers' actions in carrying out their daily activities. Perception can also be reflected in the adoption of new things introduced to farmers (Schiffman and Kanuk, 2008). The adoption of an innovation is the exact copying or imitation of how the innovation had previously been in different environments. There are several stages of innovation decisions that are usually followed by farmers, compising of knowlegde, persuasion, decision, implementation and confirmation (Rogers, 1983).

Currently, Indonesian farmers still run rice farming as the main farm business which is a hereditary culture carried out with the aim of fulfilling daily food needs. On the other hand, currently, food needs are not only met by rice, but also bread and noodles which are made of wheat flour. However, in order to fulfill these needs, we still rely on import activities. In overcoming this issue, the introduction of wheat farming has started to be carried out among farmers in the hope that farmers may be able to understand and start wheat cultivation in Indonesia. Therefore, this study attempts to understand the calculations, perceptions and attitudes of farmers towards wheat farming, considering that Indonesia is a non-wheat developing country. In regard to the 
issue, up to this moment, there has not been considerable number of research and study about it. Based on the background, this study aims to find out: 1) the farmers' calculations toward wheat farming; 2) farmers' perceptions toward wheat farming and 3) the attitude of farmers toward wheat farming. For further researches, it can be directed to examine 1) how to change the culture of rice farming into culture of wheat farming; 2) how to change subsistence rice farming into enterprise and 3) how to change rice farming as social activities to rice farming as business activities.

\section{MATERIALS AND METHOD}

This research was carried out in Klaten and Demak Regencies, Central Java, from February to March 2018. This location was chosen on the grounds for the availability of land for wheat cropping testing and also availability of human resources to run the wheat cropping testing. The type of this research is qualitative descriptive using case study approach. According to Yin (2002), the type of case study applied in this research is plural embedded case study. Embedded case study is a research that uses more than one unit of analysis. The units of analysis are calculations, perceptions and attitudes of farmers. The primary data were obtained through in-depth interviews and observation.

The concept of perceptions was seen from the viewpoint of each individual farmer toward wheat farming (Schiffman and Kanuk, 2008), while attitudes were seen from individual innovation decisions that include stages are knowledge, persuasion, decision, implementation and confirmation (Rogers, 1983). The participant selection technique is deliberate procedure techniques (purposive sampling) with three participants. The participants were farmers who already heard about wheat crops and participated in wheat cropping testing. In addition to the participants, there were also 4 key informants. Key informant is a person who knows and understands about the participants and what participants did during wheat cropping testing.

Afterwards, the data obtained were tested for validity using triangulation techniques, which include data checking from various sources, ways and times. Source triangulation was used to test the credibility of the data by checking the obtained data from several sources. Methodological triangulation were used to test the credibility of data by checking the data to the same source using different techniques. Time triangulation was used to test the credibility of data by checking the data using certain data collection techniques in different times or situations (Sugiyono, 2017). After validity testing, the data were analyzed using interactive analysis model which includes data reduction, data display and conclusion drawing.

At the stage of data reduction, researchers conduct activities to select data and information that have been obtained during research in the field. The researcher focused on simplifying the data obtained from the results of data transcripts (interview results). After the data and information obtained were summarized, the researcher employed data coding to find the same statements or statements that have the same meaning. After that, the statements of this type were given the same code. Based on the coding, the same statements will be identified and different statements will become visible. The same statements or meanings are the same, given themes. Then, statements that have the same theme were put together.

The second stage is the presentation of data. At this stage, the researchers conducted activities of presenting research data into a unit through sentences arranged systematically and logically so that it is easier to understand. These sentences will be presented as interview citations in the results of the study. The last step is drawing conclusions. At this stage, the researcher draws a conclusion as an implication of the inductive principle. This conclusion will then be verified by the researcher during the research to obtain the truth about the data and information.

\section{RESULTS AND DISCUSSION}

\section{Farmers' calculations towards wheat farming}

Basically, in the theory of learning, everyone who has tried to do a certain activity will definitely feel something about it (Schiffman and Kanuk, 2008). In this study, the activity is wheat farming. For the first time, farmers in Klaten and Demak Regencies tried to do wheat farming. Wheat farming process provides learning about how to grow, maintain and harvest the wheat. After going through the learning process, farmers experience a calculation process which is known as cognitive learning. The cognitive learning 
involves intentional mental processing in producing the desired responses, rather than an immediate response to a given stimulus.

In Economics, it is argued that farmers compare the expected results received at the harvest (revenue) with the costs (sacrifices) that have been spent. The results obtained by farmers at harvest are called production results, while the costs incurred are called production costs (Mubyarto, 1995). In general, the activity of comparing the expected results with the costs that will be incurred by farmers can be named as a calculation process. After following through the process of wheat farming, farmers experience a process of calculations within their mind which is known as knowledge. This knowledge is the initial stage of perceptions, which then creates attitudes and actions. Besides, Adawiyah et al. (2017) have also revealed that being a farmer does not require high education, but cognitive abilities make it easy for farmers to accept all new knowledge.

\section{Farming productivity}

Farmers become the entrepreneurs who manage the allocation of inputs in an efficient way to obtain maximum production. The purpose of maximizing production may help in increasing profits from their farming activities (Mubyarto, 1995). In each farming business, the products obtained are one of the indicators used by farmers to assess whether it is successful or unsuccessful. In wheat farming carried out by farmers, the products obtained only reached approximately two kilograms from $1 / 2$ ha of land area. This result failed to restore the fifty kilograms of seeds used by farmers at the beginning of planting. The following is the statement of the farmer regarding this matter:

"The results are too small in amount, not worthy, even the seeds are not covered by the result. The seeds spent were fifty kilos," (P-2, W1, 08-02-2018).

Moreover, the products obtained were also incomparable to the costs incurred by the farmers. They also added that the produces were far from their expectations. Compared to other farms the farmers have ever carried out, including rice, maize and beans farming, the results of the three farms meet the farmers' expectations better. Based on the comparison between wheat farming product with rice, maize and bean farming product, farmers concluded that the products resulting from wheat farming failed. The following is the farmers' statement on this matter:

"It failed," (P-1, W1, 05-02-2018). "I think
it is not successful yet. It does not worth the
costs," (P-2, W2, 15-02-2018). "It is not
successful. The cost incurred reaches
fifteen millions, yet the results are only two
kilograms," (P-3, W1, 08-02-2018).

\section{Farming cost}

Cost is the amount of money spent to carry out certain activities or to meet certain needs. In farming, costs are needed to meet the needs of farming activities such as fulfillment of labor, seeds, fertilizers, water and other production factors. In wheat farming carried out by the farmers, a large amount of farming cost was required, which reached fifteen million rupiahs or more. It was not proportional to the obtained product of farming. The amount of farming costs spent was allocated for fulfilling labor, water and fertilizer production factors. In addition, the planting time of the wheat which was not in the right season also caused the amount of costs spent. It is indicated by several obstacles faced by farmers in wheat farming.

Compared to other farmings that have been carried out by farmers, wheat farming required more labor. Labor are mostly used in planting seeds and weeding. A large number of labors are needed so that the planting can be undertaken immediately and weeds on the wheat planting areas can be cleaned immediately, that go up against wheat plants in obtaining nutrients. However, in fact, weeding on wheat could not be done within one day because it required few weeks to complete. It became one of the reasons why the wheat farming required large amount of cost. The following is the farmer's statement on this matter:

\section{"Yes, weeding can't be done within a day with only one person," (KI-1, W1, 12-02- 2018). "There is too much grass," (KI-3, W1, 06-03-2018).}

Furthermore, the fulfilment of water needs in wheat crops is also required. Planting wheat in the wrong season, or before the dry season, did not affect the availability of water in Klaten Regency, so that the need of water for wheat crops could still be fulfilled. Meanwhile, in Demak Regency, water could not be obtained easily right before the 
dry season came. It happened because the water source in Demak Regency is that which is rainfed. Therefore, in order to meet the water needs of wheat crops, the farmers had to make bore wells. The water inside the well was sucked out using a water pump which was then channeled to the wheat plant. The use of this water pump required a lot of gasoline to water $1 / 2$ ha of land. Therefore, in fulfilling the need of water, most of the costs were allocated to meet the fuel needs, as the farmer expressed in the following statement:

"It's indeed difficult. Currently it's rainfed. When it's dry season, the water is often unavailable. In the earlier farming, the costs rose considerably-for gasoline, the fuel." (P-2, W1, 08-02-2018).

Moreover, fertilizer production factor also became one of the factors that caused large amount of costs incurred by the farmers. It could happen because the price of side dressing fertilizer applied to wheat crops, which is $\mathrm{KCl}$, is quite expensive in their region. It reaches three hundred and fifty thousand rupiahs, while in other regions, there is a possibility of getting a lower price of the fertilizer. Hence, in order to minimize costs, farmers buy $\mathrm{KCl}$ fertilizer from other regions. In addition to these three production factors, the wrong time of planting time also results in many pests that attack wheat crops. These pests include mole crickets, rats, ants and munia birds. Pests cause the wheat plants to wither and die, and it makes the farmers need to substitute the plants with new seeds. Purchasing seeds adds to the costs used in wheat farming. The followings are the statements of the farmers regarding this matter:

"It was eaten by the mole crickets right after growing. Mole crickets are more dangerous because they eat the plants from underground, which makes the roots damaged," (P-2, W1, 08-02-2018). "It was eaten by ants and rats," (P-3, W1, 08-022018). "The pests are mole crickets, and maybe ants since there are many holes, also munia birds when it's getting dry, there are rats too," (KI-2, WI, 15-02-2018).

Reffering to the results and costs of farming that have been described by the farmers above, it can be concluded that wheat farming is not financially profitable because the results obtained are not worth the costs incurred. This is supported by Mubyarto (1995) in his theory which reveals that the purpose of farming is to obtain the highest production possible with the lowest costs. In addition, the farmers' calculations of wheat farming is also based on the traditional farming practices of the farmers that have been carried out since a long time ago. The harvest from the farms that have been worked can be used to fulfill the food needs for themselves and their families. If the amount of the yield is excessive, the excess will be sold. In contrast to the yields of wheat farming, the results are not used to meet daily food needs, instead it will be sold to meet market needs. It is in accordance with Mudiyono and Wasino (2015) who have revealed that the culture of rice cultivation in the Archipelago community has existed since pre-historic times. The agricultural process is a hereditary activity that has been carried out by the communities, especially in Java.

On the other hand, in their study, Yasin et al. (2014) have found that normalized price of other inputs contributes significantly to the lower profit in both organic and conventional wheat farmings with elasticities of -0.238 and -0.327 , respectively. The pest breakout significantly affects the profit negatively and requires timely application of plant protection measures. Besides, government should also take concrete steps to streng then extention services in qualitative and quantitative manner to improve the efficiency of the farmers. Today, agriculture starting with capital and provision of quick, easy and adequate credit should be the top priority of policy makers to improve the profit efficiency. The following is a table of comparative analysis of rice-wheat systems based on the opinions of farmers.

Table 1. Comparative analysis of rice-wheat systems

\begin{tabular}{lll}
\hline \multicolumn{1}{c}{ Aspects } & Rice & \multicolumn{1}{c}{ Wheat } \\
\hline Land management & Easy & Difficult \\
Planting & Easy & Moderately difficult \\
Watering & Easy & Difficult \\
Stitching & Easy & Easy \\
Weeding seeds & Easy & Moderately difficult \\
Fertilization & Easy & Easy \\
Pest control & Easy & Difficult \\
Harvest & Easy & Moderately difficult \\
\hline
\end{tabular}

Table 1 shows that overall, rice system is easier than wheat system. At the first step, land management of wheat system is difficult because farmers had to make gutters between beds that are 
used to water the plants. The next step, planting, is rather difficult because farmers have to plant seeds in the planting holes that have been made. The next step is watering, in wheat system, the method of watering plants is by irrigating the gutters and make sure that plants do not get excessive amount of water. It is different from rice system that the method of watering the plants is by inundating the land. The following step is stitching, both rice and wheat systems, which is easy to do because farmers just have to plant the seeds to replace the dead plants.

In terms of weeding seeds, in wheat system, this step is rather difficult because farmers control weeds manually, while in rice system, farmers use herbicide to overcome weeds. So, in rice system, the time to control weeds is faster than that in wheat system. In terms of fertilizing, in both rice and wheat systems, this step is easy to do. They just have different applications. In rice system, fertilizer is applied to the right and left of the plants, while in wheat system, fertilizer is applied by dispersing. In addition, to do pest control, in rice system, farmers used pesticide to control pests, while in wheat system, farmers control pests manually such as hunting pests. The last step is harvesting, in wheat system, this step is rather difficult to do because farmers have to harvest plant one by one. Farmers have to choose wheat crops that are already dry. The opinions of farmers are based on their experience that rice system is the kind of farming that they usually do, while wheat system is a new kind of farming for them.

\section{Farmers' perceptions towards wheat farming}

Essentially, perception is a cognitive (knowledge) process experienced by everyone. Perception is the work of the brain in understanding or judging something that happens around it. After the individual interacts with the perceived object, the perception results have two possibilities. These possibilities are positive perceptions that describe the knowledge and responses that continue to the utilization efforts and negative perceptions that describe knowledge and responses that are not in harmony with the perceived objects (Schiffman and Kanuk, 2008).

After experiencing the calculation process toward wheat farming, the farmers will experience the process of emerging farmers' perceptions. Based on farmers' calculations, wheat farming is less interesting for them. It is because the yield of wheat farming which is different from the expectations of farmers, or it can be said as a failure. Besides, it requires a large amount of costs. It is stated by the farmers in the following statement:
"Honestly, not too interested. The results are not worth as the expected. The costs incurred is too high, whereas it can't be adapted here yet," (P-2, W1, 08-02-2018). "Definitely not interested, because it is not successful, perhaps I would be interested if it was successful," (P-3, W1, 08-02-2018).

According to the statement of the farmer, it is noticeable that the wheat farming is considered as a farming business that is not yet promising or unable to provide benefits like any other farming businesses commonly carried out by farmers. On the other hand, in their study, Baga and Puspita (2013) found that farmers were less interested in wheat cultivating on the grounds that the marketing industry and supporting industries, such as processing industries, could not guarantee the market for local wheat farmers. The marketing and processing industries will guarantee the market as long as the farmers can produce the wheat continuously.

Furthermore, wheat farming is also considered complicated by farmers. It is because wheat farming has different method of maintenance compared to the other farmings. So far, farmers have become accustomed to the tradition of rice, corn and beans cultivation. The maintenance process of these three commodities is very easy. It does not take up much time for farmers, compared to wheat farming, as stated by the farmers below:

"Corns are easier. Here, when we did corn planting, we just planted it then when the fertilization day comes, we worked to fertilize it. While in wheat planting, we need to do activities everyday, keep watering it, and when it is growing, we have to water it in the morning, also in the afternoon," $(P$ 2, W1, 08-02-2018). "Planting corns, we only plant it, fertilize it, then we can leave it for our side jobs. While planting wheat, we need to be active," (P-2, W2, 15-02-2018). "The methods are too complicated. Some say that planting corns is easier. We just need to plant it, and it can be left while it's growing. Meanwhile, the wheat needs to be watered, too complicated," (KI-2, W1, 1502-2018). "Planting rice is easy, it only 
needs to be planted, fertilized and treated when it's needed. It's simple. We may need to weed, when there are some grass, " (KI3, W1, 06-03-2018).

In addition, the farmers consider that wheat farming is less suitable to be cultivated in their area because the regions belong to lowlands, where the temperature is very hot. It is in line with the research done by Wahyu et al. (2013) which has revealed that the main obstacle faced in the development of wheat is the stress in the lowland environment, especially high temperature stresses. As a result, wheat plants flower faster than it should be. The same thing was explained by Rachmadhani et al. (2017) in their research which has found that wheat plants planted in the lowlands ( $<400$ m.a.s.l.) flower faster than those planted in the highlands. This happens because the temperature conditions in the lowlands are relatively high, which speed up the flowering process. Rawson et al. (1996) added that overly high air temperature resulted in the increasing of respiratory activity, also the rapid ripening of grains.

Besides, climate factors greatly determine plant growth and production. If plants are planted outside the climate area, their productivity is often not as expected. Farmers did not consider climate change in wheat planting, but they assumed that the time was not right so that it took place in an appropriate climate too. That's why, based on farmers' experience, climate is one of the obstacles that causes the failure of wheat farming. Therefore, farmers began to think a way to deal with the climate in the future. Farmers plan is to use green houses on wheat crops when the rainy season comes. It is used to minimize the number of wheat plants that die due to frequent waterlogging. On the other hand, farmers also think that the costs will definitely be much greater, so the real step that farmers will take is to grow wheat along the lines of the season they should be. The season is the end of the rainy season. This is affirmed by Joshi et al. (2017) in their research that climate change will bring about substantial welfare losses especially for small holders who derive their livehood from agriculture. Besides, adaptation seems to be the most efficient and friendly way for farmers to reduce the negative impacts of climate change.

Direct or indirect rainfall is important for regulating time and space in flower and fruit formation in tropical plants (Handayani, 2011). Babiker et al. (2017) also revealed that the effect of location was highly significant for both falling number and rate of germination, and was significant for germination percentage. Basu et al. (2014) have added that optimum temperature that supports the growth of wheat plants is under $24^{\circ} \mathrm{C}$. Therefore, wheat crops which are needed are those which are able to adapt in the middle plains (400-800 m.a.s.1.). Therefore, the farmers said that wheat farming should be carried out on highlands. The following is the statement of the farmers regarding this matter:

"It should have been planted in highlands, maybe in Kopeng, Bandungan, Tawangmangu for the air temperature may help," (P-1, W1, 05-02-2018). "It's hot temperate areas. The wheat should be planted in cool temperate areas, " (P-2, W1, 08-02-2018)

Based on the description above, it can be concluded that farmers' perceptions toward wheat farming are more likely to be negative, as indicated by their disinterest in wheat farming. Another thing that affects the perceptions of these farmers is that wheat farming is not relevant to other farming carried out by farmers. The current farming carried out by farmers is a subsistence farming business with the main goal of fulfilling their needs, also the family's needs. Meanwhile, wheat farming is a farming business which is capable of fulfilling food modernity and becoming a modern society fashion with the main goal of gaining profits (Purnomo et al., 2010). Yudiarini (2011) has added that subsistence farmers prioritize the slogan "safety first" and prefer food crops farming. The rationality of farmers does not allow commercial crops that may endanger the substance of farmers, unless their subsistence needs got fulfilled. In addition, farming is not only an economic activity, but has become a culture of life which is full of sociocultural values of local communities.

However, there are other things that arise in the minds of farmers that may make them change their perceptions from negative to positive perceptions. It is the feeling of pride and pleasure felt by farmers after trying to carry out wheat farming. Even though the results of farming obtained did not meet their expectations, farmers gained immensely valuable experience from wheat farming. They also revealed that from wheat farming they were trained to be more 
patient and painstaking in maintaining plants. In addition, trying wheat farming is also one of the learning media for farmers to get new insights, as the following farmers said:

"Even if it has not been successful, but I am proud. Not everyone is able to plant it. I already knew what the wheat was like and how to plant it. For me, wheat planting tested our patience," (P-2, W1, 08-022018). "I'm glad. I'm able to gain knowledge and learn how to plant wheat," (P-3, W2, 02-15-2018).

\section{Farmers' attitudes towards wheat farming}

Perception will usually be demonstrated and showed in the attitudes or tendencies of farmers' actions in carrying out their daily activities. Perception can also be reflected in the adoption of new things introduced to farmers (Schiffman and Kanuk, 2008). The adoption of an innovation is the exact copying or imitation of how the innovation had previously been in different environments. There are several stages of innovation decisions that are usually gone through by farmers, including knowlegde, persuasion, decision, implementation and confirmation (Rogers, 1983). After expressing their calculations and perceptions towards wheat farming, farmers showed a tendency to attitudes towards wheat farming. Most of the farmers could not accept wheat farming yet with the reason that wheat farming had not been successfully tested in the local area, so the farmers did not put much interests in adopting it. This attitude is also based on the reason that farmers are not certain about the results that will be obtained when they run wheat farming, so further trials are needed, but on a small scale. The following is the farmers' expression on this matter:

"Because the trials have not turned out well. Farmers will usually be interested if the trials went well, the results can be expected, then they will get attracted. Can't accept it yet, maybe if it turns out well, then given an exact price, maybe we could get interested. We can't plant it, in other words it can't even live, so even if we get the solution, we are not too interested in it, " $(P$ 2, W1, 08-02-2018). "How will you plant the wheat when you do not know the result of it. Maybe if it's not too much, I can plant it. I mean, we do the trials first, and find out what's the result of one meters. We need to do trials," (P-3, W1, 08-02-2018). "If it gets successful, there may be some asking about the wheat farming results that actually only gained few kilos in half a hectare," (P-3, W2, 15-02-2018).

The attitude acted by most farmers is in line with Rogers' (1983) theory which states that most individuals will not adopt innovation without previously trying it based on probation to determine its usefulness in their own situation. These small-scale trials are often part of the decision to adopt and this is important as a means to reduce the perceived uncertainty of innovation for adopters. Most individuals who have tried innovation will turn to adoption decisions, when innovation has at least a certain level of relative superiority. It is similar to what Fachrista and Sarwendah (2014) explained in their study. Agricultural technology innovation is not directly applied by farmers. The decision of farmers to adopt agricultural technology requires time and it is influenced by the perceptions of the technology. Besides, Widiyastuti et al. (2016) have added that the social environment is one of the factors that can influence farmers to be able to receive new innovations or new information that is able to increase farmer's knowledge and insights about their farming business. The social environment is able to form farmers to become more advanced farmers, so that farmers can increase their farming productivity. The social environment also effects the decisions that will be made by farmers.

Although most farmers took a standpoint of rejecting it, there are some farmers who want to try wheat farming again later on. Farmers are eager to retry wheat farming, indicated by their willingness to prepare the land. However, financially, the farmers claimed that they were not ready for bearing the cost. Ashari (2009) has also revealed that weak capital is still one of the problems faced by agricultural businesses. Besides, Ndiema et al. (2012) revealed in their study that eighty seven point nine percent (87.9\%) of the farmers identified input cost as a major constraint and $85.1 \%$ lacked the relevant information. In addition, there are also farmers who take a stance by expressing their willingness to try wheat farming again, but on a smaller scale, to estimate the yields obtained, understand the main obstacles, and find out whether wheat farming has advantages or not compared to other 
sectors of farming business. The following is the expression of the farmers regarding the statement:

"I wanted to develop it, but get constrained by the costs. If it only required lands, I'd be ready," (P-1, W1, 05-02-2018). "I mean, I can do it if we do the trials first, not too much, maybe one kilo. I'm a patient farmer. We test it first, finding out the obstacles, whether it's about the water or the fertilization. If it turns out well, maybe we can. For example, you put fifteen thousand for the price, and then the result is one quintal from one kilo of seeds, so we get one and half million, then I will choose to plant it," (P-3, W1, 08-02-2018). "I ask for trials to find out how the results will be, whether it is a plus compared to other crops. If the trials turn out well, maybe I will get interested," (P-3, W2, 15-02-2018).

Based on the attitude shown by the farmers, it can be concluded that judging from the five stages of the adoption decision, farmers have passed the knowledge stage which means that farmers have gotten familiar with the wheat farming and have obtained knowledge about how wheat seeds look like, also with how to plant, maintain and harvest wheat crops. Presently, the farmers are in the persuasion stage which means that they have been able to show their interests and disinterests towards wheat farming. Apparently, most farmers tend to show an attitude of dislike toward wheat farming which is shown by an attitude of not being able to accept wheat farming yet. It is similar to what Wijayanti's et al. (2015) explained in their study. Farmers' response to innovation of cultivation and utilization of sorghum was $57.99 \%$, with $90 \%$ of farmers still hesitant about the application of cultivation innovations and sorghum utilization. This happened because sorghum is a newly developed technology. Perception and motivation have a positively significant effect on farmers' responses to the innovation of cultivation and utilization of sorghum. Raghav and Sen (2014) have also revealed that marginal and small farmers are reluctant to use new technology because it increases the cost of production, whereas relatively large farmers believe that technologies are good for them in terms of high yield, less pests and more benefit.

On the other hand, in this study, there were some farmers who behaved otherwise, getting interested in wheat farming. It was indicated by their willingness to try wheat farming later on. This attitude was based on their experience after trying wheat farming once. It is in line with the result of the research of Wicaksono et al. (2018) which revealed the public's great response to the introduction of wheat crops and their products in Arjasari Village, Bandung Regency. The community was interested in growing wheat and making products from wheat. The response could be seen after a counseling was held. Various variables related to public interest in developing wheat include the the people's age, prior product introduction, previous planting and interest in increasing income. It is similar to what Andriaty and Setyorini's (2012) explained in their study. Extention agents are still the main source of information for farmers. Besides, it is also in line with what is stated by Maoba (2016); Azumah et al. (2018) in their study. The extension service aims at providing the farmers with the services and quality information on the technologies and farming practices to keep them fully satisfied.

\section{Farmers' attempts to achieve success for the future wheat farming}

After experiencing wheat farming trials, farmers who showed a positive attitude tendency towards wheat farming began to think about possible ways that could be done to bring the farming to success. Based on the experience of once wheat farming trial, farmers have already discovered some of the obstacles faced in running wheat farming. These obstacles include the presence of pests and weeds on wheat crop land, the unavailability of water in Demak Regency at the time of the dry season, difficulty in obtaining $\mathrm{KCl}$ fertilizer because of the expensive price and also the rainy season which comes ahead of wheat crops harvest time. Consequently, farmers begin to think and seek ways that can be carried out to overcome all of the obstacles.

In overcoming weeds on wheat crops, farmers will conduct a test by taking few samples from wheat plants overgrown with weeds to be sprayed with herbicides. It helps to find out which herbicide is best to use to treat the weeds on wheat crops without affecting or damaging the growth of wheat plants. Farmers believe that weeds in wheat plants are similar to weeds commonly found in rice plants, as the farmer explained in the following statement: 
"For example, problem with weeds. If I take few samples, maybe a square meter, then we will find out how it will turn if I give a treatment. I believe that the wheat crops are similar to rice crops, and I guess the weeds are quite similar, it can be overcome, just like the rice," (P-1, W2, 12-02-2018).

It is carried out to support minimizing the weeds in wheat plant lands, so that the growth of wheat crops can be maximized. It is similar to what Khalil et al. (2013) explained in their study. The experiment was comprised of 6 herbicides plus hand weeding and weedy check plots. It showed affinity 50WDG followed by the mixture of Buctril super + Puma super provided better results for the control of weeds in the wheat crop. But it is not in line with the result of a research conducted by Gaba et al. (2016) which revealed herbicides are found to be more affective at controlling rare plant species than abundant weed species. These results suggest that reducing the use of herbicides by up to $50 \%$ can maintain crop production, a result confirmed by previous studies, while encouraging weed biodiversity. Food security and biodiversity conservation may, therefore, be achieved simultaneously in intensive agriculture simply by reducing the use of herbicides.

In addition, overcoming weeds using herbicides also helps to minimize the costs which are usually used to pay weeding workers. It is in line with the notion put forward by Tekle et al. (2018) in their study. In all districts, wheat yield of the Pyroxsulam treatment were better than the hand weeding and more cost was incurred in hand weeding. Afterwards, to overcome mole crickets on wheat crops, farmers will continue to use a mixture of bran and insecticides to eradicate the pests. A mixture of bran and insecticides has been proven effective in eradicating mole crickets. The experience of farmers in trying wheat farming in the wrong season shows that mole crickets are the major pests faced by them.

Moreover, other attempts that can be done to run the wheat farming well is to prepare everything needed in wheat farming activities in the beginning of the planting, especially the supply of fertilizers so that difficulties in obtaining fertilizer can be avoided. The obstacles in fulfilling water needs can be overcome by choosing the right time to plant wheat, which is at the end of the rainy season, so that the water needs of the wheat plant at the beginning of its growth can be fulfilled. Sukresna and Suminarti (2018) have added that in the cultivation of wheat plants, the even frequency of water distribution is more important than the amount of its distribution. Samekto (2008) has also revealed in his research that wheat plants do not like water. The use of water is mostly needed during flowering and seed filling only. Choosing the right planting time also helps to avoid wheat harvest time that coincides with the arrival of the rainy season, so that crop failures can be minimized or even avoided, as the following farmer stated:

"At the beginning of planting, everything has to be prepared, fertilizers, especially fertilizers," (P-2, W2, 15-02-2018).

Those attempts are prepared by the farmers, in case they will run wheat farming which targets a successful wheat farming in the future. They expect wheat farming to be able to produce satisfactory results and meet their expectations, so that it can give advantages for farmers.

\section{CONCLUSIONS}

The result of calculations shows that wheat farming is financially not profitable for farmers, which then brings in farmers' negative perceptions of wheat farming that it is considered not promising. On the other hand, farmers realize the presence of valuable experiences gained from wheat farming. This perception influences the attitude of farmers, most of who show that they could not accept wheat farming yet. Further research may examine: 1) how to change the culture of rice farming into culture of wheat farming; 2) how to change subsistence rice farming into enterprise and 3) how to change rice farming as social activities to rice farming as business activities.

\section{ACKNOWLEDGEMENT}

We thank to the Directorate General of Higher Education, Ministry of Research, Technology, and Higher Education of the Republic of Indonesia for providing the part of research fund (Grant No. 043/SPK-PUPT/PR V/4/2017). 


\section{REFERENCES}

Adawiyah, C. R., Sumardjo, \& Mulyani, E. S. (2017). Faktor-faktor yang Memengaruhi Peran Komunikasi Kelompok Tani dalam Adopsi Inovasi Teknologi Upaya Khusus (Padi, Jagung, dan Kedelai) di Jawa Timur. Agro Ekonomi, 35(2), 151-170. http://dx. doi.org/10.21082/jae.v35n2. 2017.151-170

Andriaty, E., \& Setyorini, E. (2012). Ketersediaan Sumber Infromasi Teknologi Pertanian di beberapa Kabupaten di Jawa. Perpus. Pert., 21(1), 30-35. Retrieved from http://ejurnal. litbang.pertanian.go.id/index.php/jpp/article/ view/493

Ashari. (2009). Optimalisasi Kebijakan Kredit Program Sektor Pertanian di Indonesia. Analisis Kebijakan Pertanian, 7(1), 21-42. Retrieved from http://ejurnal.litbang.perta nian.go.id/index.php /akp/article/view/4250

Azumah, S. B., Donkoh, S. A., \& Awuni, J. A. (2018). The perceived effectiveness of agricultural technology transfer methods: Evidence from rice farmers in Northern Ghana. Cogent Food \& Agriculture, 4(00), 111. https://doi.org/10.1080/23311932.2018.15 03798

Babiker, W. A., Abdelmula, A. A., Ibrahaim, H., Eldin, S., \& Gasim, M. (2017). The Effect of Location, Sowing Date and Genotype on Seed Quality Traits in Bread Wheat (Triticum aestevium). Asian Journal of Plant Science and Research, 7(3), 24-28. Retrieved from https://www.researchgate.net/publication/31 9526304_The_Effect_of_Location_Sowing Date_and_Genotype_on_Seed_Quality_Traits _in_Bread_Wheat_Triticum_aestevium

Baga, L. M., \& Puspita, A. A. D. (2013). Analisis Daya Saing dan Strategi Pengembangan Agribisnis Gandum Lokal di Indonesia. Jurnal Agribisnis Indonesia, 1(1), 9-26. Retrieved from https://journal.ipb.ac.id/index.php/jagbi /article/view/8839

Basu, S., Parya, M., Dutta, S. K., Maji, S., Jena, S., Nath, R., \& Chakraborty, K. (2014). Effect of Canopy Temperature and Stress Degree Day Index on Dry Matter Accumulation and Grain Yield of Wheat (Triticum Aestivum L.) Sown at Different Dates in the Indo-Gangetic Plains of Eastern India. Agricultural Research
Communication Centre, 48(3), 167-176. https: //doi.org/10.5958/j.09 76-058X.48.3.029

Erythrina, \& Zaini, Z. (2016). Dinamika Penelitian Gandum di Indonesia. In R. H. Praptana \& Hermanto (Eds.), Gandum Peluang Pengembangan di Indonesia (pp. 2740). Jakarta: IAARD Press. Retrieved from http://balitsereal.litbang.pertanian.go.id/wpcontent/uploads/2017/01/dinamika gdm.pdf

Fachrista, I. A., \& Sarwendah, M. (2014). Persepsi dan Tingkat Adopsi Petani terhadap Inovasi Teknologi Pengelolaan Tanaman Terpadu Padi Sawah. Agriekonomika, 3(1), 110. Retrieved from http://journal.trunojoyo.ac. id/agriekonomika/article/view/435

Gaba, S., Gabriel, E., Chadoeuf, J., Bonneu, F., \& Bregtanolle, V. (2016). Herbicides do not ensure for higher wheat yield, but eliminate rare plant species. Sci. Rep, 6. https:// doi.org/10.1038/srep30112 (2016)

Handayani, A. (2011). Pengaruh Model Tumpangsari terhadap Pertumbuhan dan Hasil Tanaman Gandum dan Tembakau. Widyariset, 14(3), 479-488. Retrieved from http:// docplayer.info/41450286-Pengaruh-modeltumpang-sari-terhadap-pertumbuhan-danhasil-tanaman-gandum-dan-tembakau.html

Hardinsyah, \& Amalia, L. (2007). Perkembangan Konsumsi Terigu dan Pangan Olahannya di Indonesia 1993-2005. Jurnal Gizi Dan Pangan, 2(1), 8-15. Retrieved from http://journal.ipb.ac.id/index.php/jgizipangan/ article/view/4360

Joshi, B., Ji, W., \& Joshi, N. B. (2017). Farm households' perception on climate change and adaptation practices: a case from mountain district of Nepal. International Journal of Climate Change Strategies and Management, 9(4), 433-445. https://doi.org/https://doi.org/ 10.1108/IJCCSM-07-2016-0099

Khalil, M. F., Hassan, G., Ahmad, G., Anwar, S., \& Khan, S. (2013). Comparative Efficacy of Herbicides on Yield and Yield Components of Wheat (Triticum aestivum L.). ARPN Journal of Agricultural and Bilogical Science, 8(1), 76-80. Retrieved from http://www.arpn journals.com/jabs/research_papers/rp_2013/ja bs_0113_517.pdf

Kurnia, T. D., Widyawati, N., Djoko, M., \& 
Endang, P. (2016). Karakter Agronomi Genotipe Gandum (Triticum Aesyivum L.) pada Lahan Tropis Dataran Rendah di Indonesia. AGRIC, $28(1$ dan 2), 95-104. Retrieved from https://www.researchgate.net /publication/312376214_KARAKTER_AGR ONOMI_GENOTIPE_GANDUM_Triticum_ Aestivum_L_PADA_LAHAN_TROPIS_DA TARAN_RENDAH_DI_INDONESIA

Maoba, S. (2016). Farmers' Perception of Agricultural Extention Service Delivery in Germiston Region, Gauteng Province, South Africa. S. Afr. J. Agric. Ext., 44(2), 167-173. http://dx.doi.org/10.17159/2413-3221/2016/v $44 \mathrm{n} 2 \mathrm{a} 415$

Mubyarto. (1995). Pengantar Ekonomi Pertanian (3rd ed.). Jakarta: LP3ES.

Mudiyono, \& Wasino. (2015). Perkembangan Tanaman Pangan di Indonesia Tahun 19451965. Journal of Indonesian History, 4(1), 3845. Retrieved from https://journal.unnes.ac.id/ sju/index.php/jih/ article/view/18986

Ndiema, A. C., Aboud, A. A., Kinyua, M. G., \& Keya, N. C. O. (2012). Farmers Perception and Adoption of Drought Tolerant Wheat Varieties in the Arid and Semi-arid Lands of Kenya. Egerton Journal of Science and Technology, 12, 90-99. Retrieved from http://egerjst. egerton.ac.ke/index.php/EJ/article/view/8

Pradeksa, Y., Darwanto, D. H., \& Masyhuri. (2014). Faktor-faktor yang Mempengaruhi Impor Gandum Indonesia. Agro Ekonomi, 24(1), 44-53. Retrieved from https:// jurnal.ugm.ac.id/jae/article/view/ 17381

Purnomo, A. S., Priyanto, S. H., \& Bayu Nuswantara. (2010). Studi Kelayakan Usaha Benih Gandum. AGRIC, 22(1), 55-66. Retrieved from https://repository.uksw.edu/ handle/123456789/6231?mode=simple

Rachmadhani, S., Damanhuri, \& Soetopo, L. (2017). Uji Daya Hasil 18 Genotip Gandum (Triticum aestivum L.) di Dataran Rendah. Jurnal Produksi Tanaman, 5(8), 1316-1320. Retrieved from http://protan.studentjournal .ub.ac.id/index.php/protan/article/view/509

Raghav, S., \& Sen, C. (2014). Socio-Economic Status of Farmers and Their Perception about Technology Adoption: A Case Study. Economic and Business Review, 2(3), 7-13.
Retrieved from https://papers.ssrn.com/sol3/ papers.cfm?abstract_id=2460173

Rawson, H. M., Zajac, M., \& Noppakoonwong, R. (1996). Effects of temperature, light and humidity during the phase encompassing pollen meiosis on floret fertility in wheat. In $\mathrm{H}$. . Rawson \& K. . Subedi (Eds.), Sterility in Wheat in Subtropical Asia: extent, causes and solutions (pp. 78-84). Pokhara: Australian Center for International Agricultural Research. Retrieved from https://www.researchgate.net/ publication/266080596_Effects_of_temperatu re_light_and_humidity_during_the_phase_en compassing_pollen_meiosis_on_floret_fertilit y_in_wheat

Rizka, S. K., Purnamadewi, Y. L., \& Hasanah, N. (2018). Produk Roti dalam Pola Konsumsi Pangan dan Keberadaan Label Halal dalam Keputusan Konsumsi Masyarakat (Kasus: Kota Bogor). Jurnal Al-Muzara'ah, 6(1), 1527. https://doi.org/10.29244/jam.6.1.15-27

Rogers, E. M. (1983). Diffusion of Innovations (Third Edit). New York: Collier Macmillan.

Samekto, R. (2008). Pengalaman dan Wawasan Penelitian Gandum (Dua Tahun Penelitian Gandum Fakultas Pertanian). Jurnal Inovasi Pertanian, 7(1), 95-102. Retrieved from https://docplayer.info/35011123-Pengalamandan-wawasan-penelitian-gandum-dua-tahunpenelitian-gandum-fakultas-pertanianuniversitas-slamet-riyadi-riyo-samekto.html

Schiffman, L., \& Kanuk, L. L. (2008). Perilaku Konsumen. Jakarta: PT. Indeks.

Sembiring, H., Diana, \& Hasnul. (2016). Kebijakan Pengembangan Gandum di Indonesia. In H. R. Praptana \& Hermanto (Eds.), Gandum Peluang Pengembangan di Indonesia (pp. 15-26). Jakarta: IAARD Press. Retrieved from http://balitsereal.litbang. pertanian.go.id/wp-content/uploads/2017/01/ hasilgdm.pdf

Sugiyono. (2017). Metode Penelitian Kualitatif: untuk penelitian yang bersifat: eksploratif, enterpretif, interaktif dan konstruktif. Bandung: Alfabeta.

Sukresna, S. C., \& Suminarti, N. E. (2018). Respon Tanaman Gandum (Triticum aestivum L.) pada Berbagai Jumlah dan Frekuensi Pemberian Air. Jurnal Produksi Tanaman, 
6(2), 308-315. Retrieved from http://protan. studentjournal.ub.ac.id/index.php/protan/articl e/view/647

Tekle, L., Hagos, H., \& Beyene, H. (2018). Evaluation of frontline demonstration of herbicide (Pyroxsulam) for weed control in bread wheat in Tigray, Nothern Ethiopia. Journal of Agricultural Extension and Rural Development, 10(1), 20-27. https://doi.org/ 10.5897/JAERD2017.0910

Wahyu, Y., Samosir, A. P., \& Budiarti, S. G. (2013). Adaptabilitas Genotipe Gandum Introduksi di Dataran Rendah. Bul. Agrohorti, 1(1), 1-6. Retrieved from https://journal.ipb. ac.id/index.php/bulagron/article/view/6260

Wahyuniarti, D., \& Prabowo. (2014). Penge lompokan Komoditi Bahan Pangan Pokok dengan Metode Analytical Hierarchy Process. Buletin Ilmiah Litbang Perdagangan, 8(2), 163-182. Retrieved from https://www. semanticscholar.org/paper/PENGELOMPOK AN-KOMODITI-BAHAN-PANGANPOKOK-DENGAN-Prabowo/2888dd1f1764d 9997bbefe7a1a34e0d8047dfa98

Wicaksono, F. Y., Maxiselly, Y., Nurmala, T., Suherman, P. U., Fauzan, A., \& Nurdin, A. M. (2018). Respons Masyarakat terhadap Pengenalan Tanaman Gandum dan Produkproduknya di Desa Arjasari Kecamatan Arjasari Kabupaten Bandung. Jurnal Aplikasi Ipteks Untuk Masyarakat, 7(1), 32-37. Retrieved from http://jurnal.unpad.ac.id/ dharmakarya/article/view/14740

Widiyastuti, Widiyanti, E., \& Sutarto. (2016). Persepsi Petani terhadap Pengembangan System of Rice Intensification (SRI) di Kecamatan Moga Kabupaten Pemalang. AGRISTA, 4(3), 476-485. Retrieved from https://www.neliti.com/id/publications/18458 5/persepsi-petani-terhadap-pengembangansystem-of-rice-intensification-sri-di-keca

Wijayanti, A., Subejo, \& Harsoyo. (2015). Respons Petani terhadap Inovasi Budidaya dan Pemanfaatan Sorgum di Kecamatan Srandakan Kabupaten Bantul. Agro Ekonomi, 26(2), 179-191. Retrieved from https://jurnal. ugm.ac.id/jae/article/view/17270

Yasin, M. A., Ashfaq, M., Adil, S. A., \& Khuda, B. (2014). Profit Efficiency of Organic vs Conventional Wheat Profit Efficiency of Organic vs Conventional Wheat Production in Rice-Wheat Zone of Punjab, Pakistan. Journal of Agriculture Research, 52(3), 439-452. Retrieved from https://apply.jar.punjab.gov. pk/upload/1414328704_114_13._4305_comp osed.pdf

Yin, R. K. (2002). Studi Kasus: Desain dan Metode. Jakarta: PT. Raja Grafindo Persada.

Yudiarini, N. (2011). Perubahan Pertanian Subsisten Tradisional ke Pertanian Komersial. DwijenAGRO, 2(1). Retrieved from http:// ejournal.undwi.ac.id/index.php/dwijenagro/art icle/view/271/0 